\title{
Papillary Carcinoma Arising in Thyroglossal Duct Cyst: A Retrospective Analysis (Cancer of the Thyroid or Primary Cancer of the Thyroglossal Cyst)
}

\author{
Paolo Gamba*, Umberto Pignatelli, Giampiero D’Addazio, Gabriella Licursi, Luca Gentile, \\ Ugo Moz
}

Department of Otorhinolaryngology, Head and Neck Surgery, Poliambulanza Foundation Hospital, Brescia, Italy

Email: *paolo-gamba@libero.it

How to cite this paper: Gamba, P., Pignatelli, U., D’Addazio, G., Licursi, G., Gentile, L. and Moz, U. (2018) Papillary Carcinoma Arising in Thyroglossal Duct Cyst: A Retrospective Analysis (Cancer of the Thyroid or Primary Cancer of the Thyroglossal Cyst). Open Access Library Journal, 5: e4259. https://doi.org/10.4236/oalib.1104259

Received: December 15, 2017

Accepted: January 8, 2018

Published: January 11, 2018

Copyright ( $\odot 2018$ by authors and Open Access Library Inc.

This work is licensed under the Creative Commons Attribution International License (CC BY 4.0).

http://creativecommons.org/licenses/by/4.0/

\begin{abstract}
Thyroglossal duct cysts are one of the most common congenital abnormalities of the cervical region. Complications of these swellings are rare, and among these, appearance of a carcinoma has also been noted. Thyroglossal duct cyst carcinoma (TGDC) is a rare entity and its management is controversial. The incidence of thyroid papillary carcinoma in thyroglossal duct cyst is less than $1 \%$, in most cases, the diagnosis is made postoperatively. We report the case of an adult female patient with a papillary carcinoma arising in a thyroglossal duct cyst. Our aim is defining a clinical protocol to diagnose the thyreoglossal duct carcinoma through clinical features, radiological investigations, cytological and histopathological examinations and, through this diagnostic protocol, to choose the best surgical approach. The literature contains 300 cases of this pathology; papillary histotype constitutes about $80 \%$, then squamocellular carcinoma, mixed folliculo-papillary carcinoma and adenocarcinoma follow. The literature suggests two different hypotheses: neoplasia originating from ectopic thyroid tissue and plurifocal theory. The adopted diagnostic investigations are: ultrasonography, Fine Needle Aspiration Biopsy (FNAB), Magnetic Resonance Imaging (MRI). Our patient was treated using a modified Sistrunk's procedure operation, in which thyroidectomy proved crucial for the correct diagnosis and continuation of appropriate treatment. Our case confirms the difficulty in distinguishing a primitive thyroglossal duct carcinoma from a synchronous metastatic papillary carcinoma of the thyroid. This dilemma often remains unresolved. The two different surgical approaches reported in the literature, one more conservative and the other more aggressive, apparently alternatives are instead complementary and adequate when strict
\end{abstract}


diagnostic criteria and adequate follow-up, are observed. The first year follow-up includes the thyroglobulin level determination and a neck ecografic scan every 3 months. The patient has been following for two years without any metastasis.

\section{Subject Areas}

Oncology

\section{Keywords}

Thyroglossal Duct, Thyroglossal Cyst, Thyroid Carcinoma, Papillary

Carcinoma, Thyroglossal Duct Cyst Carcinoma, Sistrunk Procedure

\section{Introduction}

Recent biomolecular studies have identified the bio-genetical mechanisms of thyroid morphogenesis and differentiation; this gives us the opportunity to understand thyroid malformative abnormalities due to morpho-genetical errors. These errors cause an abnormal dislocation of the primordial median rudimentary thyroid, determining the development of thyroid tissue in different districts (lingual, mediastinal ad also intracardiac). In some cases, for this same reason, due to these genetic errors, if the duct fails to obliterate, it may give rise to the development of a fistular passage (thyroglossal duct cyst). The thyroglossal duct cyst is the outcome of the persistence and of the cystic growth of the remnants of the thyroglossal tract [1] [2] [3]. Recently, specific follicular thyroid cell transcriptional factors have been identified which are responsible, selectively, for the thyroid genic expression of TTF-1, TTF-2 and PAX-8, each one of these genes is also expressed in stem cells and are different from the follicular thyroid cells, the association of these three factors is characteristic of the hormonogenetic thyroid cells [4] [5] [6]. The thyroglossal duct cyst is one of the most common congenital malformation cervical (about 70\%), 50\% of these cases appearing in patients aged 20 or younger and the prevalence of location of the cyst is along the midline (75\%), in para-median position in the remaining $25 \%$. The thyroglossal duct cyst papillary carcinoma incidence is about $1 \%$. This neoplasia is characterized by a relatively non aggressive behavior with rare involvement of the thyroid gland and locoregional lymphnodes spread. Brentano, in 1911, defined the first carcinoma of the thyroglossal duct [7]. This carcinoma can appear during the childhood, but the peak incidence is between the forth and the fifth decades, females are affected slightly more often than males, with a 3:2 ratio [8]. The papillary hystotype is about $80 \%$ of all the thyroglossal carcinomas, followed by mixed folliculo-papillary carcinoma (8\%), squamocellular carcinoma (6\%) and the remaining $6 \%$ concerns Hurtle cells carcinoma, follicular carcinoma and anaplastic carcinoma [9] [10] [11]. 


\section{Case Report}

A 40 years old woman presents before us with a 5 years' history of a great anterior midline neck mass, enlarging during the last months. At the physical examination we can see an ovoidal mass, located in hyoid region, covered by normal skin, about $5 \mathrm{~cm}$ in diameter; palpation reveals a painless, mobile, non-tender, elastic mass. Ultrasound guided Fine Needle Aspiration Biopsy demonstrates that the lesion is arising, probably, in a thyroglossal duct, however some cytocariological abnormalityes are displayed in some foci, in particular, there is a moderate grade of anemacrocytosis with ground glass nuclei, worthy of further hystologic diagnostic deepening in order to reject a concomitant intracystic papillary carcinoma. A RMI, performed with and without paramagnetic contrast (Gd-DPTA), integrated by neck T1-weighted FAT-SAT acquisitions, shows cystic ovoidal lesion with regular border, located along the median cervico-anterior line of the neck below the hyoid bone, having transverse diameter about $3 \mathrm{~cm}$ long, and extending $6 \mathrm{~cm}$, craniocaudally, hyperintense signalling on T2-weightened, omogeneous on T1-weightened, without mdc, acquisitions, insinuating itself inside the strap muscle in infrahyoidal region. Inside the lesion a solid nest is recognizable (at infra-hyoid epiglottic axial plane levels) developing in the median and paramedian right region, having maximum transverse diameter of about $13 \mathrm{~mm}$ and showing clear, marked enhancement after the administration of the mdc i.v. These RM findings are related to the presence of a large median cystic lesion in the neck: probably thyroglossal duct cyst with solid nucleus demonstrating clear enhancement after the administration of mdc i.v. This finding does not allow excluding that the lesion lies inside an ectopic remnant of thyroid tissue contained in a thyroglossal duct cyst. Some lymphnodes, moderately greater in number and in size, are present, bilaterally, at level I and II (Figure 1 and Figure 2). The patient, therefore, undergoes median cervicotomy

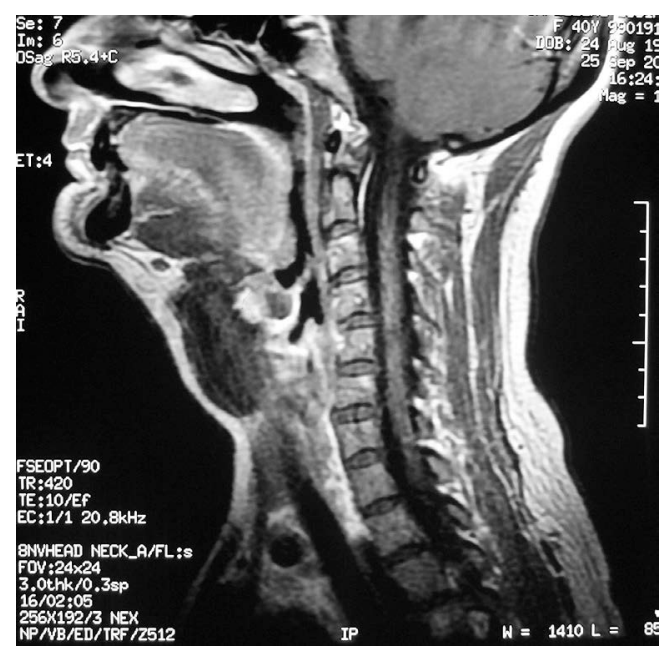

Figure 1. T1W, FAT SAT, lateral view, magnetic resonance image demonstrating the cystic ovoidal lesion located along the median anterior line of the neck below the hyoid bone, having tranverse diameter about 6 $\mathrm{cm}$. 
with removal of a portion of hyoid bone (Sistrunk's Tecnique). The hystopathologic examination of the material obtained during surgery confirmed the presence of a smooth, $4 \mathrm{~cm}$ in diameter, adhering to a $1.5 \mathrm{~cm}$ portion of bone, cystic lesion whose wall and lumen contain neoplastic nests organized in papillary structures having nuclear pseudo-inclusions. Further, there is no evidence of hyoid bone infiltration. (Figure 3) The immunohystochemical examination with TTF-1, Cytocheratine, HBME-1 positivity and CD56 negativity in these neoplastic elements. This morphological description suggests a papillary carcinoma arising in a thyroglossal duct cyst (Figure 4 and Figure 5). The first year follow-up

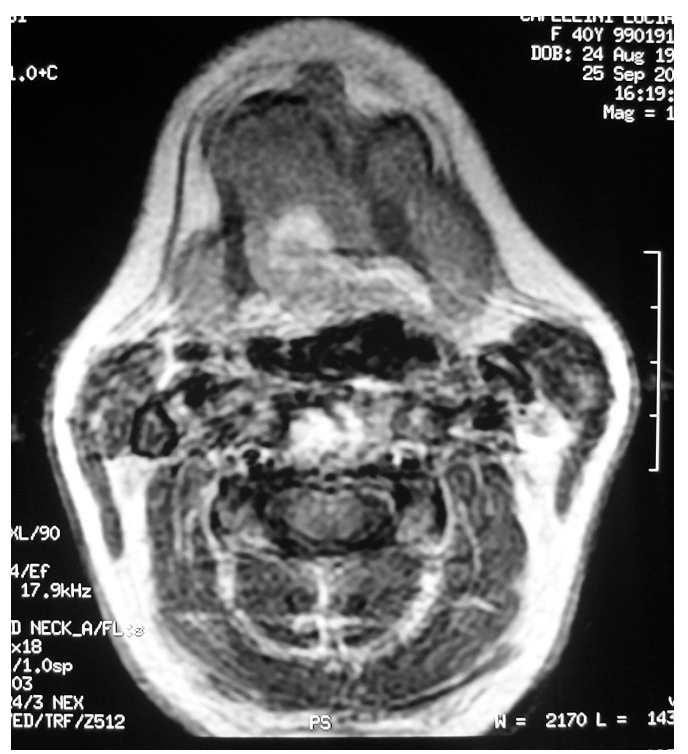

Figure 2. T1W, axial view, magnetic resonance imaging of the neck shows anteromedial neck lesion with hyperintense signal. Inside the lesion a solid nest is recognizable developing in the median and a paramedian righ region having a transverse diameter of about $13 \mathrm{~mm}$ and shoving clear marked enhancement.

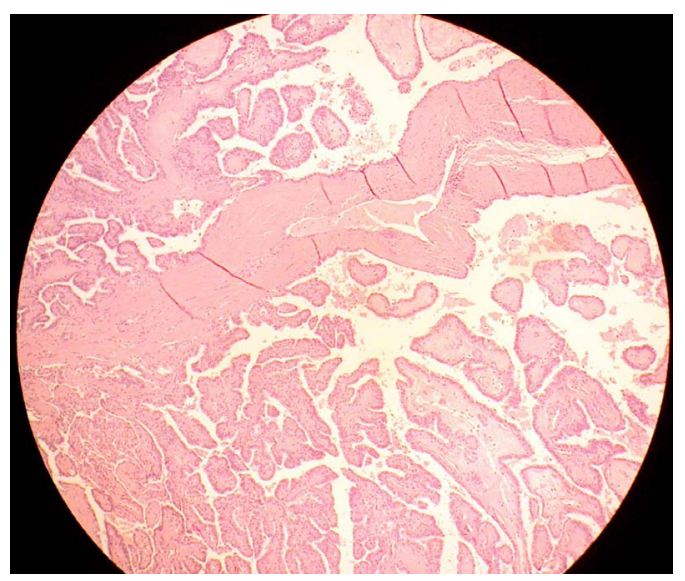

Figure 3. Papillary carcinoma evolving from a thyroglossal duct cyst. Cytocariological abnormalityes are visible in some foci, in particular, there is a moderate grade of anemacrocytosis with ground glass nuclei. (Stain: Hematoxylin \& Eosin, original magnification $\times 10$.) 


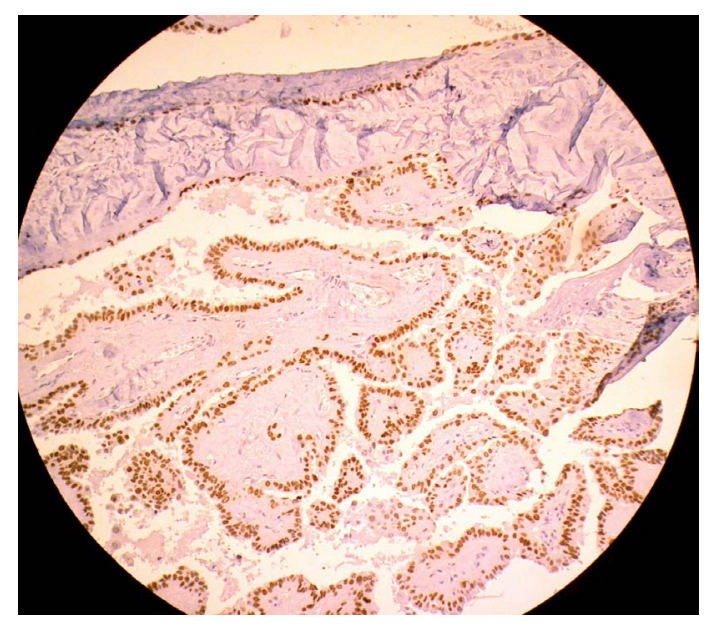

Figure 4. The immunohystochemical examination has proved TTF-1, Cytocheratine, HBME-1 positivity and CD56 negativity in these neoplastic elements. This morphological description suggests a papillary carcinoma arising in a thyroglossal duct cyst (Stain: TTF-1; Original magnification $\times 10)$.

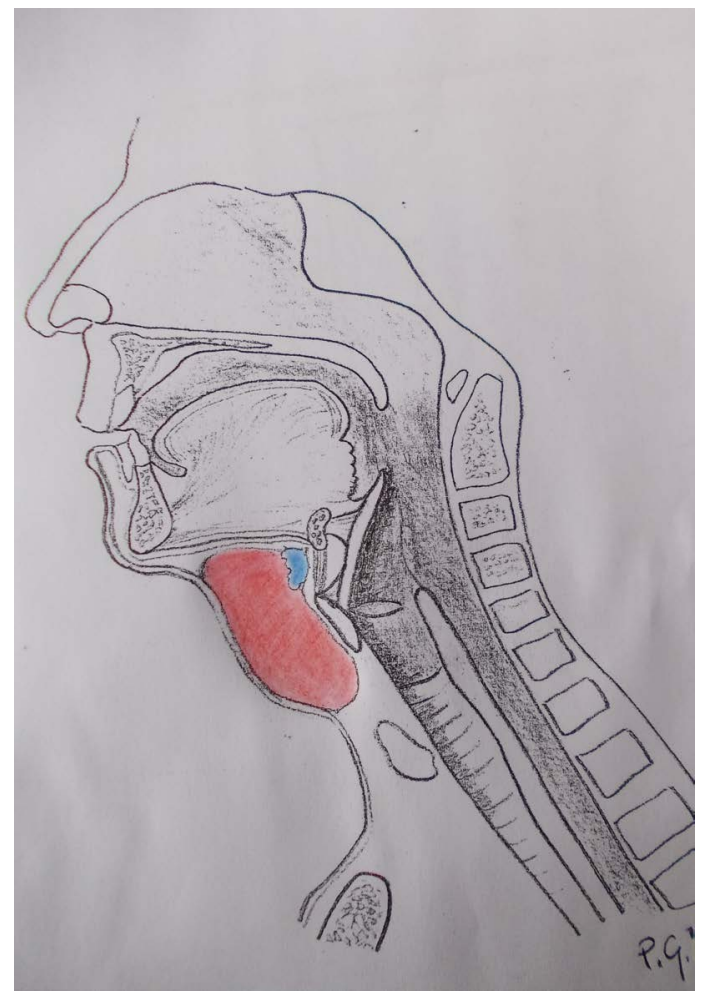

Figure 5. Red: image demonstrating the cystic ovoidal lesion located along the median anterior line of the neck below the hyoid bone. Blue: inside the lesion a solid nest is recognizable developing in the median and paramedian right region. (Sketch performed by Paolo Gamba.)

includes the thyroglobulin level determination and a neck ecografic scan every 3 months. The patient has been following for two years without any metastasis. 


\section{Discussion}

The thyroglossal duct carcinoma management is greatly debated, particularly when thyroid gland is clinically normal. Some authors support the thesis that tyroglossal duct carcinoma originates within ectopic thyroid tissue, contained inside the cyst; other authors sustain the thesis of a metastasis deriving from the thyroid gland. Accordingly, the surgical approach too is greatly debated: some authors think adeguate the so called Sistrunk's procedure when thyroid gland is normo-functioning. In 1920 Sistrunk [12] described a procedure to remove a thyroglossal cyst, which was based on the embriologic origin knowledge of the lesion. In this procedure the cyst, the median portion of hyoid bone and the tract of the thyroglossal duct, extending from the foramen cecum at the base of the tongue, to the hyoid bone, are removed in continuity. This technique is effective in low risk patients, according to: age, tumor dimension, prior thyroid diseases, capsular non-invasion, clinically and ultrasonographically normal lymphnodes, thyroid normo-conformation and normo-functioning [13] [14] [15]. Some authors, support the multifocality theory of the papillary carcinoma, prefer to perform total thyroidectomy with or without node dissection [16] [17]. Here we support the pre-surgical work-up importance consisting of: neck MRI, neck ultrasound scan, ultrasonographically guided Fine Needle Aspiration [18] [19] [20]. Even if histology must give the definitive diagnosis, these pre-surgical examinations give the indications of a papillary neoplastic lesion, its localization, and its relations with the next structures and may direct the correct surgical strategy. Ouu case confirms the difficulty in distinguishing a primitive thyroglossal duct carcinoma from a synchronous metastatic papillary carcinoma of the thyroid. This dilemma often remains unresolved [21] [22]. Long-term follow-up is necessary for patients with thyroid carcinoma arising in a TGDC [23]. In view of the frequent co-existence of thyroid cancer in these patients, we would recommend detailed thyroid evaluation and, eventually, total thyroidectomy at initial diagnosis of TGDC carcinoma (Table 1).

\section{Conclusion}

Our aim is to emphasize that significant attention must be paid to the pre-operative evaluation of the patient, the conclusions of the diagnostic phase can directly address towards the first choice surgery. The preoperative protocol we have done has given us the suspect of the presence of an intracystic thyroglossal duct papillary neoplasia, the hystopathologic examination of the material obtained during surgery confirmed, in fact, our pre-surgical diagnosis. So we have had the confirmation that ultrasonography, FNAB and MRI are essential to choose the surgical strategy and, at the same time, to achieve the definitive diagnosis of the lesion. Surgical Sistrunk's procedure is adequate when thyroid gland is clinically and radiologically normal. Papillary thyroid carcinoma arising in thyroglossal duct cysts is a very rare malignant tumor. In spite of the multifocal character of several of our cases, their analysis showed that the 
Table 1. Review cases of papillary carcinoma: case reports and review (PubMed-Indexed for MEDLINE).

\begin{tabular}{|c|c|c|c|c|}
\hline \multicolumn{5}{|c|}{ Reported cases of papillary carcinoma arising from a thyroglossal duct } \\
\hline No. & Authors & Age & Sex & Notes \\
\hline & Brentano (1911) & & & \\
\hline & Sistrunk (1920) & & & The surgical management of cysts of the thyroglossal tract. \\
\hline $\begin{array}{l}\text { Sydney } \\
\text { (Australia) }\end{array}$ & Tew (1995) & & & $\begin{array}{l}\text { The incidence and pathological features of palpillary thyroid carcinoma arising in } \\
\text { the TDC were reviewed and compared with papillary thyroid carcinoma arising } \\
\text { elsewhere in the thyroid gland. } \\
\text { The incidence of papillary thyroid carcinoma arising in the TD is no different to } \\
\text { that arising elsewhere in the gland. The difference in number of carcinomas related } \\
\text { only to the volume of follicular thyroid tissue present in the gland proper. That } \\
\text { being the case, there is no reason to treat these cancers differently from papillary } \\
\text { thyroid carcinoma elsewhere in the gland. }\end{array}$ \\
\hline $\begin{array}{l}\text { Bologna } \\
\text { (Italy) }\end{array}$ & Sorrenti (1995) & & & $\begin{array}{l}\text { Some Authors thought that these carcinomas were metastases of thyroid } \\
\text { carcinomas. Now, following demonstration of normal thyroid tissue occurrence in } \\
\text { the wall of thyroglossal ducr cysts, it is almost universally accepted that a } \\
\text { carcinoma may arise from thyroglossal remnants. The foci of cancer found in } \\
\text { thr thyroid reported in literature are a result of the plurifocality of papillary } \\
\text { carcinoma. The Authors suggest that the Sistrunk procedure in an adequate, } \\
\text { sufficient treatment if the carcinoma is limited to the cyst's walls. }\end{array}$ \\
\hline $\begin{array}{l}\text { Birmingham } \\
\text { (England) }\end{array}$ & Hilger (1995) & & & $\begin{array}{l}\text { The management is discussed on the bases of the current rationale for treatment of } \\
\text { thyroid cancer. }\end{array}$ \\
\hline $\begin{array}{l}\text { Beyrouth } \\
\text { (Liban) }\end{array}$ & Daou (1996) & & & $\begin{array}{l}\text { Controversies exist concerning its nature (cancer of the thyroid or primary cancer } \\
\text { of the thyroglossal cyst) and its treatment (Sistrunk's operation alone or combined } \\
\text { with thyroidectomy). }\end{array}$ \\
\hline $\begin{array}{l}\text { Toronto } \\
\text { (Canada) }\end{array}$ & Kwan (1996) & 38 & M & $\begin{array}{l}\text { Pathological examination showed both a concurrent papillary carcinoma and a } \\
\text { squamous cell carcinoma, Treatment consisted of a near-total thyroidectomy, } \\
\text { ablative radioactive iodine and adjuvant external radiation therapy. }\end{array}$ \\
\hline $\begin{array}{l}\text { Liverpool } \\
\quad(\mathrm{UK})\end{array}$ & Ghaneim (1997) & & & $\begin{array}{l}\text { Thirty pts undergoing surgery for diagnosi of TDC have been reviewed. Sistrunk's } \\
\text { procedure is the operation of choice but when histological examination of a TDC } \\
\text { reveals a papillary carcinoma, totsl thyroidectomy should be considered. }\end{array}$ \\
\hline $\begin{array}{l}\text { Danville } \\
\text { (USA) }\end{array}$ & Kennedy (1998) & & & $\begin{array}{l}3 \text { cases TDCc, The authors recommend that a thyroglossal duct cyst with a } \\
\text { microscopic focus of papilaary carcinoma, without cyst wall invasion, be managed } \\
\text { with a Sistrunk procedure. Treatment of all other thyroglossal ducr papillary } \\
\text { carcimoma should include removal of all thyroid tissue followed by radioactive } \\
\text { iodine treatment. }\end{array}$ \\
\hline $\begin{array}{l}\text { Valencia } \\
\text { (Spain) }\end{array}$ & $\begin{array}{l}\text { Vera-Sempere } \\
\quad(1998)\end{array}$ & 55 & M & $\begin{array}{l}\text { Papillary Carcinoma arising from a thyroglossal duct. Sistrunk procedure. } \\
\text { Preoperative CT performed showed irregular calcium deposits adjacent to the hyod } \\
\text { bone. }\end{array}$ \\
\hline & Miccoli (1998) & & & $\begin{array}{l}\text { Thyroid ca in a thyroglossal duct cyst: tumor resection alone or accompanied by } \\
\text { total thyroidectomy? }\end{array}$ \\
\hline $\begin{array}{l}\text { London } \\
\text { (UK) }\end{array}$ & O’Connell (1998) & & & $\begin{array}{l}8 \text { pts aged from } 14 \text { to } 71 \text { years (mean } 44.6 \text { ): } 5 \mathrm{M} \text { and } 3 \mathrm{~F}: 4 \text { surgical excision; and } 3 \\
\text { surgical exicion plus thyroidectomy followed by radioiodine following and only } \\
\text { biopsy in one patient with lingual thyroid carcinoma. }\end{array}$ \\
\hline $\begin{array}{l}\text { Washington } \\
\text { (USA) }\end{array}$ & Ewing (1999) & & & 11 cases of TDC including 2 cases containing papillary carcinoma. \\
\hline $\begin{array}{c}\text { Berlin } \\
\text { (Germany) }\end{array}$ & Kurzen (1999) & 22 & M & $\begin{array}{l}\text { Tumor excision, bilateral neck dissection and total thyroidectomy. Histhopatology } \\
\text { revealed a dystopic papillary carcinoma in a thyroglossal duct cyst, no } \\
\text { abnormalities in the thyroid gland but a metastatic carcinoma was uncovered in } \\
\text { ipsilateral lymphonode in the jugular foramen area. }\end{array}$ \\
\hline $\begin{array}{c}\text { Campinas } \\
\text { (Brazil) }\end{array}$ & Martins (1999) & 21 & $\mathrm{~F}$ & Sistrunk procedure. Follow-up 2 years. \\
\hline
\end{tabular}


Continued

\begin{tabular}{|c|c|c|c|c|}
\hline $\begin{array}{l}\text { Quito } \\
\text { (Ecuador) }\end{array}$ & Pacheco Ojeda & & & $\begin{array}{l}43 \text { pts TDC: In } 5 \text { patients (12\%) papillary carcinoma. Follow-up } 23 \text { month. A } \\
\text { Sistrunk prodedure is usually curative }\end{array}$ \\
\hline \multirow[t]{2}{*}{$\begin{array}{l}\text { Casablanca } \\
\text { (Marocco) }\end{array}$} & Sahraoui (2000) & 36 & $\mathrm{~F}$ & Sistrunk procedure. \\
\hline & Dedivitis (2000) & 36 & $\mathrm{~F}$ & $\begin{array}{l}\text { Papillary Carcinoma arising from a thyroglossal duct cyst. The main question is } \\
\text { what to do with the thyroid gland, there still is controversy about thyroid removal } \\
\text { for a papillary carcinoma, but the entire patient should receive suppressive doses of } \\
\text { thyroid hormone. }\end{array}$ \\
\hline $\begin{array}{l}\text { Rome } \\
\text { (Italy) }\end{array}$ & D’Annibale (2000) & 39 & M & $\begin{array}{l}\text { Most thyroid cancers at the time of surgery are confined to the thyroid gland, } \\
\text { infiltrating the adjacent structures in approximately } 20 \% \text { of cases and the } \\
\text { local-regional lymphonodes in } 8 \text { to } 11.5 \% \text {. Thyroid papillary carcinoma is } \\
\text { multifocal in } 21 \% \text { of cases. The multifocal nature of the cancer makes total } \\
\text { thyroidectomy mandatory at the same time as surgery is performed to remove } \\
\text { the cyst. }\end{array}$ \\
\hline $\begin{array}{l}\text { Pittsburgh } \\
\text { (USA) }\end{array}$ & Branstetter & $6 \mathrm{pts}$ & & $\begin{array}{l}\text { CT appearance of thyroglossal duct carcinoma: carcinoma should be considere in } \\
\text { thyroglossal duct cysts that have a mural nodule or calcification or both. Ages from } \\
14 \text { to } 59 \text { years. }\end{array}$ \\
\hline $\begin{array}{l}\text { California } \\
\text { (USA) }\end{array}$ & Doshi (2001) & 14 pts & & $\begin{array}{l}\text { Large case series: long term follow-up incorporating clinical examination is } \\
\text { manadatory. }\end{array}$ \\
\hline \multirow[t]{2}{*}{$\begin{array}{l}\text { New York } \\
\text { (USA) }\end{array}$} & Patel $^{18}(2002)$ & $57 \mathrm{pts}$ & & $\begin{array}{l}\text { The addition of total thyroidectomy to Sistrunk operation did not have a significant } \\
\text { impact on outcome }(\mathrm{p}=0.1) \text {. The Sistrunk operation is adequate for most patients } \\
\text { with incidentally diagnosed TGDC carcinoma in the presence of a clinically and } \\
\text { radiologically normal thyroid gland. Results of adequate excision using the Sistrunk } \\
\text { operation are excellent and the concept of risk-group should be used to identify } \\
\text { patients, who would benefit from more aggressive treatment. }\end{array}$ \\
\hline & Ducic (2002) & & & Thyroglossal duct cysts in the elderly population. \\
\hline $\begin{array}{l}\text { Amsterdam } \\
\text { (Holland) }\end{array}$ & Goslings (2002) & 15 & M & $\begin{array}{l}\text { In } 10 \% \text { - } 40 \% \text { of the patients who undergo a subsequent thyroidectomy, malignant } \\
\text { focuses are also found I the thyroid. In view of this multifocal occurrence and the } \\
\text { fact that in most cases the diagnosis of carcinoma is only made after the operation, } \\
\text { which often implies uncertainty about oncological radicalness, the authors advice } \\
\text { to perform a near (-total) thyroidectomy as the standard procedure in case of } \\
\text { thyriglossal duct carcinoma. After this adequate treatment with 131I should be } \\
\text { given. }\end{array}$ \\
\hline $\begin{array}{l}\text { Foggia } \\
\text { (Italy) }\end{array}$ & Cignarelli (2002) & 3 cases & & $\begin{array}{l}\text { Rapid growth of the cystic nass, and the presence of a mural nodule on US, } \\
\text { especially with calcifications, must raise the physician's suspicion for a cancer } \\
\text { arising in TDC. }\end{array}$ \\
\hline \multirow{3}{*}{$\begin{array}{c}\text { Duzce } \\
\text { (Turkey) }\end{array}$} & Aluffi $^{13}(2003)$ & & & $\begin{array}{l}\text { Two cases, currenttly, most authors agree about their primary origin ex novo from } \\
\text { ectopic thyroid tissue in the ctst. In most cases the diagnosis of thyroglossal duct } \\
\text { carcinoma (TD) is not mede until histopathological examination has been } \\
\text { performed on a resected cyst without any suspected clinical sign of malignancy. } \\
\text { The definition of the correct surgical treatment for these carcinomas is still } \\
\text { controversial. Most authors maintain that resection of a TDC with the Sistrunk } \\
\text { procedure can be considered oncologically adequate then dealing with a } \\
\text { differentiated carcinoma without extracapsular invasion and/or lymphonode } \\
\text { metastase and with a normal thyroid. }\end{array}$ \\
\hline & Ozturk (2003) & 11 & M & $\begin{array}{l}\text { After a primary Sistrunk procedure, the cyst and tract extending to the forame } \\
\text { caecum at the base of the tongue in continuity with the midportion of the hyod } \\
\text { bone were resected. }\end{array}$ \\
\hline & Naghavi (2003) & 28 & M & $\begin{array}{l}\text { We recommend that thyroglossal duct cyst with a microscopic focus of papillary } \\
\text { carcinoma without cyst wall invasion be managed with Sistrunk procedure along } \\
\text { with effective suppressant dose of thyroxine. }\end{array}$ \\
\hline
\end{tabular}


Mean

Age 38,

$1 y$

Mazzaferri

(2004)

Peretz (2004)

Shahin (2005)

Demir (2005)

Plaza (2006)

Kandogan (2008)

Berni Canani

Paris

(France)

Hwasun

(Korea)

Korea

Kwon (2011)

Cincinati (USA)

Kim (2011)

Al Ain

(Unite Arab

Emirates)

Yokohama

(Japan)

Sydney

(Australia)
Balalaa (2011) 31

Gomi (2011) 11

Forest (2011)
Extent of surgery in thyroglossal duct carcinoma: reflections on a series on a $14 \mathrm{~F}$ series eighteen cases. Thyroglossal duct neoplasm was represented by papillary $4 \mathrm{M}$ carcinoma in 16 cases; thyroid histology demonstrated papillary carcinoma in 6 cases $(33.3 \%)$.

Thyroid cancer in thyroglossal duct remnants: a diagnostic and therapeutic dilemma.

Tyroglossal duct carcinoma in children.

4 cases od papillary thyroglossal duct: one patient needed a thyroidectomy fifteen years after the initial management of the PTDC; 2 patients were treated by a Sistrunk procedure associated with total thyroidectomy. A microscopic focus of papillary carcinoma without cyst wall invasion, can be managed bi Sistrunk procedure with the need for long-term follow-up. Treatment of all other thyroglossal duct papillary carcinoma should include thyroidectomy followed by radioactive iodine treatment.

Thyroglossal duct cyst: a cytopathologic study of 26 cases.

2 cases micropapillary carcinoma was detected tyroid gland of both patients. Simultaneous existence of papillary carcinoma in the thyroid gland and thyroglossal duct cyst in two patients.

Time to close the debate? 5 new cases and proposal of a definitive algorithm for treatment.

Papillary carcinoma with associated microcarcinoma of the thyroid and without cervical lymphonode metastasis. Tumor diameter $2 \mathrm{~cm}$.

$2.5 \mathrm{~cm}$ thyroglossal duct with a $0.6 \mathrm{~cm}$ focus of follicular variant of papillary M carcinoma. Papillary Carcinoma arising from a thyroglossal duct in a patient with thyroid hemiagenesis.

Total thyroidectomy after the complete excision of the cyst is currently F the recommended treatment for the papillary carcinoma followed by a substitute M hormonal therapy, were achieved. It was shows that a latent thyroid cancer could develop even 15 years after the initial excision of the thyroglossal cyst.

Histopathological examination of the specimen revealed papillary carcinoma arising in the TGDC and papillary microcarcinoma of the thyroid gland without F extrathyroidal extension. Surgeons should be aware of TGDC carcinoma during surgical planning and postoperative treatment and should differentiate this carcinoma from an anterior midline neck mass.

Prymary thyroglossal duct cyst papillary carcinoma with cervical node metastasis.

SPECT/CT precisely localized neck iodine uptake. In small numbers of patients, treatment is affected. Spect/CT should be used when available in thyroid carcinoma patients. In three of 13 studies with neck uptake, SPECT/CT provided no useful additional information.

Although the Sistrunk procedure is often regarded as adequate, controversies exist concerning the need for thyroidectomy depending on histopathological findings.

Papillary carcinoma with extensive squamous metaplasia arising from thyroglossal duct cyst in an 11-years-old-girl.

TGDC: 9 patients, femal predominance, median age 44 years. A total thyroidectomy was performed in eight of nine patients; the median size carcinoma was $10 \mathrm{~mm}$. And received radioactive iodine therapy and suppressive doses of thyroxine. A sistrunk therapy procedure is the minimum therapeutic procedure, coupled with a total thyroidectomy for higher-risk cancers. 


\section{Continued}

\section{Erzurum}

(Turkey)

Belgrade, Serbia.

Dzodic

(2012)

Seoul, (Republic of Korea)

Byeon

(2012)

Saskatchewan, (Canada)

Seoul (Korea).

Busan, (Republic of Korea).

Kitakyushu, (Japan)

Yamada S

Mean

Thessaloniki

(Greece)

Chrisoulidou

(2013)

Rome

(Italy)

Proia

(2014)

Ardabil

Maleki

(Iran)

(2014)

Puducherri

Sudharsanan

(India) cosmesis. However, careful consideration in selecting appropriate cases is required and prospective trials should be conducted to recognize long-term outcomes and to overcome potential limitations.

Though Sistrunk's procedure is adequate treatment for TDC, based on low,

F moderate, and high risk stratification, recommendations for further management of incidental TPC in TDC is discussed.

There were ten patients who were diagnosed with TGDC carcinoma at our institution. All patients underwent pre-operative fine-needle aspiration biopsy (FNAB). Nine patients were suspected of having papillary carcinoma following cytology. The Sistrunk operation (SO) was performed in four patients, SO with total thyroidectomy (SO/TT) was performed in three patients, and SO/TT with neck dissection was performed in three patients.

Thyroglossal duct carcinomas (TGDC) are rare, with approximately 274 reported cases since the first report in 1915. The prevalence of carcinomas in surgically removed thyroglossal duct cyst (TGD) is less than $1 \%$. The usual recommended treatment for this condition is the Sistrunk operation, but controversies remain regarding the need for total or partial thyroidectomy.

Although metastatic thyroid papillary carcinoma of cervical lymph node was an important differential diagnosis owing to various overlapping clinicopathological features, coexistent benign lining epithelium or thyroid follicles, a histological hallmark of TDC, were present in the current case.

Long-term follow-up is necessary for patients with thyroid carcinoma arising in a $4 \mathrm{~F} 2$ TGDC. In view of the frequent co-existence of thyroid cancer in these patients, we M would recommend detailed thyroid evaluation and, eventually, total thyroidectomy at initial diagnosis of TGDC carcinoma.

Our patient was treated using a modified Sistrunk operation, in which thyroidectomy proved crucial for the correct diagnosis and continuation of

F appropriate treatment. Our case confirms the difficulty in distinguishing a primitive thyroglossal duct carcinoma from a synchronous metastatic papillary carcinoma of the thyroid.

In our case there was neither invasion to adjacent tissue nor lymph node involvement. The patient then underwent total thyroidectomy and bilateral neck

F dissection. The patient was treated with radioactive iodide and thyroid suppression therapy was given as adjuvant treatment. The patient has been following for two years without any metastasis.

M Thyroglossal Duct Cyst of an elderly patient.

TGDC: Thyroglossal duct cyst carcinoma. 
prognosis in the vast majority of patients with TDC carcinoma is excellent. Moreover, we found no relation between outcome and surgical procedure.

\section{Consent}

We have informed and obtained the patient' consent.

\section{References}

[1] Lanzafame, S., Caltabiano, R., Puzzo, L. and Imme, A. (2006) Expression of Thyroid Transcription Factor 1 (TTF-1) in Extra Thyroidal Sites: Papillary Thyroid Carcinoma of Branchial Cleft Cysts and Thyroglosal Duct Cysts and Struma Ovarii. Patologica, 98, 640-644.

[2] Falconieri, G., Della Libera, D. and Zanella, M. (2001) Papillary Thyroid Carcinoma of the Thyroglossal Duct Cyst: Comparative Cytohistologic and Immunochemical Study of 2 New Cases and Review of the Literature. International Journal of Surgical Pathology, 9, 65-71. https://doi.org/10.1177/106689690100900114

[3] Shahin, A., Burroughs, F.H., Kirby, J.B. and Ali, S.Z. (2005) Thyroglossal Duct Cyst: A Cytopathologic Study of 26 Cases. Diagnostic Cytopathology, 33, 365-369. https://doi.org/10.1002/dc.20346

[4] Missero, C., Cobellis, G., De Felice, M. and Di Lauro, R. (1998) Molecular Events Involved in Differentiation of Thiroid Follicular Cells. Molecular and Cellular Endocrinology, 25, 37-43. https://doi.org/10.1016/S0303-7207(98)00027-6

[5] Damante, G., Tell, G. and Di Lauro, R. (2001) A Inique Combination of Transcription Factors Controls Differentiation of Thyroid Cells. Progress in Nucleic Acid Research and Molecular Biology, 66, 307-356. https://doi.org/10.1016/S0079-6603(00)66033-6

[6] Patel, S.G., Escrig, M., Shaha, A.R., Singh, B. and Shah, J.P. (2002) Management of Well-Differentiated Thyroid Carcinoma Presenting within a Thyroglossal Duct Cyst. Journal of Surgical Oncology, 79, 134-139. https://doi.org/10.1002/jso.10059

[7] Brentano, H. (1911) Struma Aberrata Lingual Mit Druzen Metastasen. Deutsch Med Wuchenschr, 37, 665.

[8] Weiss, S.D. and Orlich, C.C. (1991) Primary Papillary Carcinoma of a Thyroglossal Duct Cyst: Report of a Case and Literature Review. Br J Surg, 78, 87-89. https://doi.org/10.1002/bjs.1800780127

[9] Shah, S., Kadakia, S., Khorsandi, A., Andersen, A., Iacob, C. and Shin, E. (2015) Squamous Cell Carcinoma in a Thyroglossal Duct Cyst: A Case Report with Review of the Literature. American Journal of Otolaryngology, 36, 460-462. https://doi.org/10.1016/j.amjoto.2015.01.012

[10] Heshmati, H.M., Fatourechi, V. and Van Heerden, J.A. (1997) Thyroglossal Duct Carcinoma: Report of 12 Cases. Mayo Clinic Proceedings, 72, 315-319. https://doi.org/10.4065/72.4.315

[11] Lehnerdt, K.H., Mehlhorn, J., Nurnberger, H. and Deitmer, T. (2006) Simultaneous Papillary Carcinoma in a Thyroglossal Duct Remnant and the Thyroid Gland. Laryngorhinologie, 85, 909-912. https://doi.org/10.1055/s-2006-925090

[12] Sistrunk, W.E. (1920) The Surgical Management of Cysts of the Thyroglossal Tract. Annals of Surgery, 71, 121-122. https://doi.org/10.1097/00000658-192002000-00002

[13] Aluffi, P., Pino, M., Boldorini, R. and Pia, F. (2003) Papillary Thyroid Carcinoma Identified after Sistrunk Procedure: Report of Two Cases and Review of the Litera- 
ture. Tumori, 89, 207-210.

[14] Motamed, M. and McGlashan, J.A. (2004) Thyroglossal Duct Carcinoma. Current Opinion in Otolaryngology \& Head and Neck Surgery, 12, 106-109.

https://doi.org/10.1097/00020840-200404000-00009

[15] Falvo, L., Giacomelli, L., Vanni, B., Marzollo, A., Guerriero, G. and De Antoni, E. (2006) Papillary Thyroid Carcinoma in Thyroglossal Duct: Case Reports and Literature Review. Int Surg, 91, 141-146.

[16] Kazemi, M., Assadi, M., Kazemi, A.A. and Ghazvini, L.A. (2006) Primary Papillary Carcinoma in a Thyroglossal Duct Cyst. Hellenic Journal of Nuclear Medicine, 9, 39-40.

[17] Peretz, A., Leiberman, E., Kapelushnik, J. and Hershkovitz, E. (2004) Thiroglossal Duct Carcinoma in Children: Case Presentation and Review of the Literature. Thyroid, 14, 777-785. https://doi.org/10.1089/thy.2004.14.777

[18] Miccoli, P., Minuto, M.N., Galleri, D., Puccini, M. and Berti, P. (2004) Extent of Surgery in Thyroglossal Duct Carcinoma: Reflections on a Series of Eighteen Cases. Thyroid, 14, 121-123. https://doi.org/10.1089/105072504322880355

[19] Kennedy, T.L., Whitaker, M. and Wadih, G. (1998) Thyroglossal Duct Carcinoma: A Rational Approach to Management. Laryngoscope, 108, 1154-1158. https://doi.org/10.1097/00005537-199808000-00010

[20] Pezzolla, A., Paradies, D., Lattarulo, S., Ciampolillo, A. and Madami, L. (2015) Thyroglossal Duct Carcinoma. The American Surgeon, 81, E25-E27.

[21] Koybasioglu, F., Simsek, G.G. and Onal, B.U. (2006) Tall Cell Variant of Papillary Carcinoma Arising from a Thyroglossal Cyst: Report a Case with Diagnosis by Fine Needle Aspiration Cytology. Acta Cytologica, 50, 221-224. https://doi.org/10.1159/000325937

[22] Yang, Y.J., Haghir, S., Wanamaker, J.R. and Powers, C.N. (2000) Diagnosis of Papillary Carcinoma in a Thyroglossal Duct Cyst by Fine-Needle Aspiration Biopsy. Archives of Pathology \& Laboratory Medicine, 124, 139-142.

[23] Sudharsanan, S., Vijayakumar, C., Dharanya, S., Elamurugan, T.P. and Manwar, A.S. (2017) A Rare Case of Carcinoma in the Thyroglossal Duct Cyst of an Elderly Patient. Cureus, 9, e1365. 